\title{
Perceived Ease of Use and Perceived Usefulness of Social Media for e-Learning in Libyan Higher Education: A Structural Equation Modeling Analysis
}

\author{
Ali Mohamed Elkaseh, Kok Wai Wong, and Chun Che Fung
}

\begin{abstract}
Social networking media are becoming popular among students and teachers in higher education. Researchers have also started to explore the use of social networking media for teaching and learning in higher education. Social networking media have offered new opportunities for sharing, creating and interacting between students and teachers. However, to implement and adopt such technology, there is a need to investigate the factors that influence the acceptance of the students and the teachers using such technologies as a tool for learning and teaching. In this paper, a study based on the Technology Acceptance Model (TAM), which emphasizes on Perceived Ease of Use and Perceived Usefulness together with Behavior Intention to use new technologies, is used to test the factors of using social networking media for e-learning in Libyan higher education. A quantitative research method was employed utilizing survey method. Research data was collected from a sample of teachers and students from four universities in the Libyan higher educational sector. Structural Equation Modeling was carried out to examine the predictive behaviour of the proposed factors of the research model. It was discovered from the study that the Perceived Ease of Use and Perceived Usefulness are important factors for predicting a student's and teachers' behavioral intention to use social networking media for e-learning in Libyan higher education.
\end{abstract}

Index Terms-Libyan higher education, social networking media, perceived ease of use, perceived usefulness, e-learning.

\section{INTRODUCTION}

The impact of the Internet on the education sector has taken both teachers' and students' attention in recent years. New generations of Web 2.0 and Web 3.0 have added more enthusiasm and excitement for people to spend many hours on internet based applications, especially social networking media [1]. A big portion of the social networking media users are youths who are mostly university students [2]. Many studies have reported that Facebook is the most common social networking tool used where $85-99 \%$ of the university students use it for all aspects of life, including for educational purposes [3]. A recent study of about 3000 college students, from USA, indicated that $90 \%$ of students utilize Facebook and $37 \%$ of them use Twitter to share information [4].

Social networking media (e.g Facebook, Linkedin or Twitter) received a lot of attention due to the high take up rate across the world. Social networking media have made communication, collaboration and interaction possible and

Manuscript received September 2, 2014; revised November 2, 2014.

The authors are with Murdoch University, Australia (e-mail: a.elkaseh@murdoch.edu.au). more efficiently. Consequently, they have been introduced to support educational activities [5]. Social networking media have been able to create a revolution in the communication fields for information and knowledge sharing [5]. This revolution has changed the manner of how people interact and communicate with each other, including how they exchange, access and share knowledge [6]. Social networking technologies have several advantages such as create new methods of interaction, collaboration, and the ability to share and create content [7]. With these characteristics, social networking media are recognized as important tools for reshaping the learning and educational environment. By implementing e-learning tools according to the advantages of the social networking media, it can be used to provide interactive and collaborative learning environment [8]

Recently, Libyan younger generation, in particular higher education learners have shown that they prefer using new technologies and also their willingness to utilize all technological devices through social networking media [9]. On another research, Elkaseh, et al. [10], and Rhema and Miliszewska [11] have demonstrated that e-learning is getting interest from the Libyan Higher Education sector. However, there is no research from the literature to investigate the utilization of social networking media with e-learning in Libya.

The purpose of this paper is therefore to investigate the perceived usefulness and the perceived ease of use of social networking media in e-learning for Libyan higher education.

\section{LITERATURE REVIEW}

In the past several years, the increased use of social networking media has become a global phenomenon. With the rapid development of technology utilized for communicating with others and the prevalence of the Internet, Social Networking media has become one of the main activities that is performed on the Internet, with websites like Facebook, MySpace, Bebo, Xanga, and Friendster [12]. Social networking media is acknowledged to be a good supplementary technology for e-learning systems [13]. Social networking media can be used by instructors to create e-learning experiences, and more importantly, learners can use social networking media in ways that can assist their learning experience [14]. There are some concerns from educators and parents on the growing utilization of social networking media and its impact on pedagogy particularly between students and teachers in higher education [15].

Many studies discovered that social networking media 
influence the effectiveness of learning and teaching in general. For example, social networking media demonstrated in many studies have discovered a positive impact on learning and teaching foreign languages as they can enhance and improve students' written and oral language skills [16]. Recently, many universities are providing access to social networking media to be utilized as e-learning tools to assist learners to access contents, course materials, and work together with colleagues as well as with teachers [17].

The preceding literature recognized the obstacles and challenges which related to using social networking media in higher education institutions. Jones et al. [18] conducted a study of the usability of social networking between college students in the UK. The study consists of 76 participants for questionnaire and 14 participants for interview. The study concluded that there are five main challenges of social networking media and its association to learning such as copyright issues, study originality, feeling of information constraint, and teachers sometimes are not ready and could not understand how to use and take advantage of the social networking media in their classrooms.

The driving reasons for adoption of social networking media are the functionality, progressively ubiquitous access flexibility, and convenience of social technologies [19]. It has claimed that social networking media enhances social constructivist technique to learning. They probably can improve learners' construction of understanding, and enhance student's interaction [20]. An additional advantage of social networking media offered on the internet is that they are often free or only require marginal investment.

Although social networking media have been considered by learners as a social technology rather than a formal tool for learning and teaching [21], it can have an impact on learners' performance. There has been different research which identified four main advantages of social media use in higher education institutions. These include, improving learning motivation, enhancing relationship, developing collaborative abilities, and offering personalized course material [22]. Given the fact that utilizing social networking media in higher education provides enormous advantages, it is not without some concerns. It has been indicated that one of the most serious concerns regarding social networking media is in their usage, the probability of spending lots of time on something that less important [23].

Due to the issues found with social networking media in the above literature, this study examines the impact of using social networking media on perceived ease of use and perceived usefulness of students' and teachers' using e-learning for teaching and learning in Libyan higher education.

\section{RESEARCH QUESTIONS}

Although social media technologies have been used in learning, there are two research questions that need further investigation for Libyan higher education before it can be incorporated into the e-learning framework in Libya.

Q1: Does the intensity of using social media impact on the perceived ease of use and the perceived usefulness of students' using e-learning in Libyan higher education?
Q2: Does the intensity of using social media impact on the perceived ease of use and the perceived usefulness of teachers' using e-learning for teaching in Libyan higher education?

\section{RESEARCH MODEL AND HYPOTHESES}

This study investigates the perceived ease of use and perceived usefulness of social networking media in e-learning as teaching and learning tools in Libyan higher education. To examine the factors that could impact the acceptance of such technology in learning, an extended Technology Acceptance Model (TAM) was used. There are many researchers that have continuously stated that the TAM was useful in explaining and predicting the technology use in different situations [24].

\section{A. Technology Acceptance Model (TAM)}

The Technology Acceptance Model (TAM) was developed from the Theory of Reasoned Action (TRA), in order to describe an individual's IT acceptance behaviour. The objective of TAM is to examine why users' attitudes and beliefs influence their acceptance or rejection of IT. TAM aims to provide an explanation of the determinants of the adoption and use of IT [25]. It suggests two specific attitudes: perceived usefulness (PU) and perceived ease of use (PEOU) that determine one's behavioural intention to use a technology [26]. Davis [27] examined the theory and found that while both perceived ease of use and perceived usefulness play a role in predicting user attitudes towards using a system, the influence of perceived usefulness was $50 \%$ stronger than that of perceived ease of use. Perceived usefulness and perceived ease of use have been tested to describe or predict behavioural intention on different technologies such as e-banking, e-commerce, e-learning, e-library, e-tax filing, telemedicine technology, word processing, social networking media, smartcard and microcomputer [28]. Many researchers have applied TAM in e-learning studies and have found that the perceived ease of use and the perceived usefulness have significant effects on an individual's behavioral intention to use e-learning systems [29]. Based on TAM, we propose a research model that can examine the impact of the perceived ease of use and the perceived usefulness of social networking media for e-learning in Libyan education (see Fig. 1). The model includes variables such as social networking media, perceived variables, attitude, and behavioral intention.

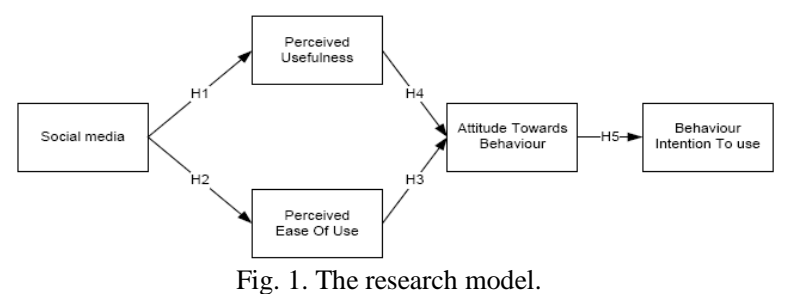

\section{B. Social Networking Media}

According to Adamson [30] social networking media is a vital tool for teaching and learning, and should be used extensively for this purpose. Jackson [31] reported that the usage of social networking media in education institutions can 
have a positive effect on students' learning outcomes. Adopting a social networking media approach provides learners with valuable resources for utilizing the Internet as a tool in order to improve their understanding [32]. Several studies reported the effect of using social networking media on students' and teachers' in e-learning [29]. Therefore, the following alternate hypotheses are proposed for this study.

H1a: Social networking media use influences students' perceived Usefulness of e-learning in Libyan higher education.

H1b: Social networking media use influences teachers' perceived Usefulness of e-learning in Libyan higher education.

H2a: Social networking media use influences students' perceived Ease of Use of e-learning in Libyan higher education.

H2b: Social networking media use influences teachers' perceived Ease of Use of e-learning in Libyan higher education.

\section{Perceived Ease of Use and Perceive Usefulness}

In TAM, Perceived Ease of Use and Perceived Usefulness are two variables which have impact on the behavioural intentions to use a system [33]. The relationship between the perceived usefulness and perceived ease of use have been discovered by a number of studies [34]. Teo [35] and Seif, et al. [36] also found direct impact between perceived usefulness (PU) and attitude towards use in the context acceptance e-learning and factors that affect teachers and students to use technology. This study examines the relationship between the factors, through the following alternate hypothses:

H3a: Perceived Ease of Use influences students' Attitude Towards Behaviour of using e-learning in Libyan higher education.

H3b: Perceived Ease of Use influences teachers' Attitude Towards Behaviour of using e-learning in Libyan higher education.

H4a: Perceived Usefulness influences students' Attitude Towards Behaviour of using e-learning in Libyan higher education.

H4b: Perceived Usefulness influences teachers' Attitude Towards Behaviour of using e-learning in Libyan higher education.

\section{Attitude towards Use (ATU)}

Attitude is defined as a person's positive or negative feeling about performing the target behaviour [37]. Awareness goes along with attitude and "positive attitude towards ICT is widely recognized as a necessary condition for the effective implementation" [38]. Rhema, et al. [39] stated that e-learning success is affected by different types of factors including users' attitudes towards e-learning as well as their satisfaction with using technology during teaching/learning experience. Moreover, research has shown that knowledge of the educators' attitude of the technology and its influence on their job helps in developing more appropriate technology training programs for teaching. This also facilitates better technology-integration with the pedagogy [40]. Similarly, there are strong relationships between educators' attitude and their success in using technology for learning [41]. Research has shown that the more positive attitude towards the use of new technology, provides greater intention to use [42]. Therefore, the following hypotheses are proposed (the null hypotheses present no influence):

H5a: Attitude Towards Behaviour influences students' Behavioural Intention to Use e-learning in Libyan higher education.

H5b: Attitude Towards Behaviour influences teachers' Behavioural Intention to Use e-learning in Libyan higher education.

\section{RESEARCH METHODOLOGY}

\section{A. Research Design}

In order to answer research questions, qualitative and quantitative methods were used. In this research, both of these research methodologies are used and implemented throughout the study known as mixed approach. The method adopted under the mixed methodology approach is survey.

Survey research is most commonly used in non-experimental design and is considered most appropriate for theory testing. A survey research could support the external validity of the study results from managerial perspectives [43].

There are many types of surveys such as oral survey, written survey, online survey and example survey. This study focuses on oral and written surveys. According to Fowler [44], a written survey can be grouped as administered questionnaires, mail survey or drop-off survey. A mail survey was used in this study.

The interview was conducted after respondents had completed the questionnaire survey. At the end of the questionnaire, participants were asked to participate in the interview.

The interview was voluntary. The purpose of the interview was to seek qualitative data regarding the factors affecting the adoption of e-learning in Libyan higher education and to get students and teachers comments and opinions on e-learning. Findings from these interviews were used to extend and to provide further details in addition to the questionnaire. Interviews can elicit more in-depth details and information from the respondents and allow researchers to discover a significant amount of knowledge about the respondents perceptual experience, values, attitudes, feelings and views of events [45].

\section{B. Population and Sample}

The population in this study consists of students and teachers from Libyan Higher education. The surveys were divided in two parts. The first part was a self-administered survey, which were targeted at students and teachers. The second part was a follow up interview for students and teachers. The sampling of the self-administered survey was described as follows: First: participants were recruited from four universities: two private and two public universities. These universities had been chosen for the following reasons: 1) These universities reflect the geographical diversity in Libya, where two of them are in urban areas and two of them from rural areas. 
2) For public universities, University of Tripoli and Elmergib University had been chosen because they were larger universities in the region and they had students coming from all surrounding areas thus covering a large geographical area.

3) Private universities had been chosen because they are under funding system.

The proportion of the students and teachers obtained from each university is not important, since the minimum sample size was achieved.

TABLE I: DEMOGRAPHIC PROFILE OF STUDENTS AND TEACHERS

\begin{tabular}{|c|c|c|c|c|}
\hline & \multicolumn{2}{|c|}{ Student } & \multicolumn{2}{|c|}{ Teacher } \\
\hline \multicolumn{5}{|c|}{ - } \\
\hline \multicolumn{5}{|l|}{ Gender } \\
\hline Male & 114 & 35.8 & 113 & 62.1 \\
\hline Female & 04 & 64.2 & 69 & 37.9 \\
\hline \multicolumn{5}{|l|}{ Age } \\
\hline $18-29$ years & 299 & 94.3 & 49 & 26.9 \\
\hline $30-49$ years & 17 & 5.3 & 88 & 48.4 \\
\hline $50+$ & 1 & 0.3 & 45 & 24.7 \\
\hline \multicolumn{5}{|l|}{ University Type } \\
\hline Private & 82 & 25.8 & 26 & 14.3 \\
\hline Public & 36 & 74.2 & 156 & 85.7 \\
\hline \multicolumn{5}{|l|}{ Social networking Use } \\
\hline Yes & 293 & 92.1 & 152 & 83.5 \\
\hline No & 25 & 7.9 & 30 & 16.5 \\
\hline \multicolumn{5}{|l|}{ Social networking used } \\
\hline Facebook & 253 & 79.6 & 117 & 64.3 \\
\hline Twitter & 24 & 7.5 & 18 & 9.9 \\
\hline Blackboard & 4 & 1.3 & 6 & 3.3 \\
\hline Other & 13 & 4.1 & 12 & 6.6 \\
\hline No choice & 23 & 7.2 & 29 & 15.9 \\
\hline \multicolumn{5}{|c|}{ Using of social networking media } \\
\hline Never & 24 & 7.5 & 29 & 15.9 \\
\hline Once a month & 16 & 5.0 & 8 & 8.4 \\
\hline Once a week & 26 & 8.2 & 13 & 7.1 \\
\hline Once a day & 115 & 36.2 & 61 & 33.5 \\
\hline More than on & day & 137 & 43.1 & 71 \\
\hline
\end{tabular}

In the second part, interview was conducted after respondents had completed the questionnaire survey. At the end of the questionnaire, participants were asked to participate in voluntary interview. The sample size in an interview survey depends on the number of voluntary participants and there was no minimum size required for this part of the study. The target population in this research was the students and teachers from four universities: two public and two private from Libyan higher education. Therefore 400 student questionnaires and 400 teachers, questionnaires were distributed to the students and teachers in four universities. From the 400 questionnaires distributed to the students, 318 were returned that were eligible for the analysis and 27 questionnaires were discarded because there were missing data due to lack of completeness by the participants. The overall student response rate for this study is $79.5 \%$. From the 400 questionnaires distributed to the teachers, 182 were returned in a form that was eligible for the analysis and 7 questionnaires were dismissed because they contained missing data. The overall teacher's responses rate for this study was $45.5 \%$. The questionnaire responses were analyzed using version 21 of the Statistical Package for Social Program (SPSS). Table I shows demographic and descriptive statistics for students and teachers.

\section{DATA ANALYSIS}

Analysis of Moment Structures (AMOS) Version 21 was used for testing the causal relationships and examining the hypotheses research model. A two-stage model building approach was conducted to analyze the data in this research. First, the measurement model was tested to validate the validity and reliability of the constructs. Second, the structural model was estimated utilizing hypotheses testing. The estimation of the measurement model and structural model was conducted using Maximum Likelihood Estimation (MLE).

\section{A. Measurement Model Development}

The unidimensionality and internal consistency assessment of the items of each factor were assessed. Exploratory Factor Analysis (EFA) was conducted to offer evidence of unidimensionality of the items of each measurement. The purpose of the measurement model was to determine the reliability and validity of a set of items in each latent construct. Cronbach's Alpha was conducted to assess the reliability of each factor. According to Hair et al. [46], Cronbach's Alpha score of at least 0.7 can be considered as acceptable of internal consistency. Reliability value of each factor is shown in Tables II and IV. All reliability values those are greater than 0.7 are considered as acceptable. The construct validity was examined by investigating the convergent validity and discriminant validity. Convergent validity was measured utilizing composite reliability and Average Variance Extracted (AVE) [47]. A commonly used value for Composite reliability should be at least 0.7 whereas the Average Variance Extracted (AVE) should be 0.5 or higher to be considered acceptable [48]. According to Tables II and IV, the loading value of each factor is greater than or equal to 0.5 and also reach the significance level of $p<0.001$.

Discriminant validity measures the difference between a construct and its indicators from another construct and its indicators [49]. It is also used to measure the extent to which a construct is really different from other constructs [50]. Fornell and Larcker [51] states that the correlations among items in any two constructs should be less than the square root of the AVE shared by items within a construct.

For acceptable discriminant validity, each indicator highly measures its intended constructs [52]. Additionally, the AVE shared between a construct and its measures should be higher than the AVE shared by the constructs in the model [53]. In this study the correlation method was used to determine discriminant validity, see Table III and Table V.

Tables II and IV show the results of the convergent validity. All constructs show good convergent validity because all the criteria were met. 
TABLE II: CONSTRUCT RELIABILITY FOR STUDENT

\begin{tabular}{|c|c|c|c|c|c|}
\hline Factor & Item & $\begin{array}{l}\text { Factor } \\
\text { Loading }\end{array}$ & $\mathbf{C R}$ & AVE & $\begin{array}{l}\text { Cronbach's } \\
\text { alpha }\end{array}$ \\
\hline \multirow[t]{4}{*}{ Social media } & SM1 & 0.897 & 0.847 & 0.650 & 0.829 \\
\hline & $\mathrm{SM} 2$ & 0.734 & & & \\
\hline & SM3 & 0.668 & & & \\
\hline & SM4 & 0.633 & & & \\
\hline \multirow{4}{*}{$\begin{array}{l}\text { Perceived } \\
\text { Ease of Use }\end{array}$} & EASE1 & 0.675 & 0.819 & 0.533 & 0.828 \\
\hline & EASE2 & 0.831 & & & \\
\hline & EASE3 & 0.659 & & & \\
\hline & EASE4 & 0.745 & & & \\
\hline \multirow{3}{*}{$\begin{array}{l}\text { Perceived } \\
\text { Usefulness }\end{array}$} & USEF3 & 0.541 & 0.768 & 0.533 & 0.770 \\
\hline & USEF4 & 0.810 & & & \\
\hline & USEF5 & 0.807 & & & \\
\hline \multirow[t]{3}{*}{ Attitude } & ATT3 & 0.691 & 0.763 & 0.517 & 0.768 \\
\hline & ATT4 & 0.737 & & & \\
\hline & ATT5 & 0.730 & & & \\
\hline \multirow{3}{*}{$\begin{array}{l}\text { Behavioral } \\
\text { Intention }\end{array}$} & INT1 & 0.778 & 0.831 & 0.623 & 0.832 \\
\hline & INT2 & 0.713 & & & \\
\hline & INT3 & 0.878 & & & \\
\hline
\end{tabular}

Note: $\mathrm{CR}=$ Composite Reliability; AVE= Average Variance Extracted

TABLE III: CORRELATION BETWEEN THE VARIABLES IN THE MODEL OF STUDENTS

\begin{tabular}{lccccc}
\hline \multicolumn{6}{c}{ STUDENTS } \\
\hline 1 & 1 & 2 & 3 & 4 & 5 \\
\hline 2 & 1.000 & \multicolumn{5}{l}{} \\
\hline 3 & .356 & 1.000 &. \\
\hline 4 & .256 & .452 & 1.000 \\
\hline 5 & .464 & .460 & .345 & 1.000 \\
\hline
\end{tabular}

TABLE IV: CONSTRUCT RELIABILITY FOR TEACHER

\begin{tabular}{lllllc}
\hline Factor & Item & $\begin{array}{l}\text { Factor } \\
\text { Loading }\end{array}$ & CR & AVE & $\begin{array}{l}\text { Cronbach's } \\
\text { alpha }\end{array}$ \\
\hline Social media & SM1 & 0.721 & 0.824 & 0.610 & 0.836 \\
& SM3 & 0.817 & & & \\
& SM4 & 0.802 & & & \\
Perceived & EASE1 & 0.820 & 0.886 & 0.722 & 0.891 \\
Ease of Use & EASE3 & 0.837 & & & \\
& EASE4 & 0.892 & & & \\
Perceived & USEF2 & 0.621 & 0.797 & 0.571 & 0.812 \\
Usefulness & USEF3 & 0.847 & & & \\
& USEF5 & 0.782 & & & \\
Attitude & ATT2 & 0.657 & 0.750 & 0.507 & 0.840 \\
& ATT3 & 0.862 & & & \\
& ATT5 & 0.590 & & & \\
Behavioral & INT1 & 0.848 & 0.726 & 0.888 & 0.904 \\
Intention & INT2 & 0.897 & & & \\
& INT4 & 0.809 & & &
\end{tabular}

Note: CR= Composite Reliability; AVE= Average Variance Extracted
TABLE V: CORRELATION BETWEEN THE VARIABLES IN THE MODEL OF

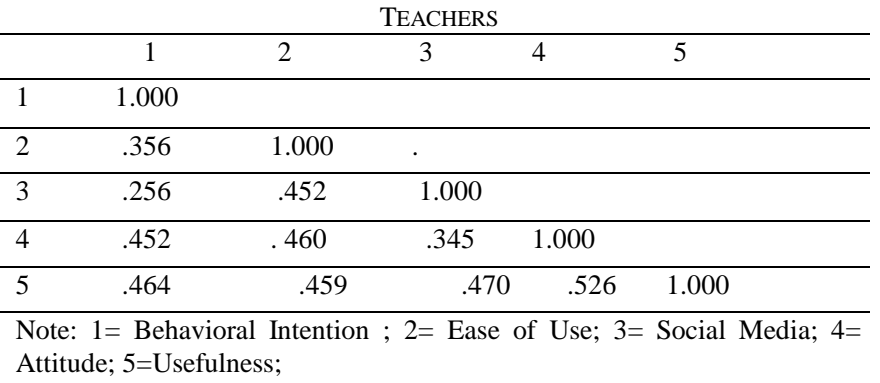

\section{B. Structural Model Evaluation}

Analysis of Moment Structure (AMOS) Version 21 was employed to evaluate the goodness fit of the structural model, so as to examine the significance of hypothesized paths in the research model and also to examine the variance $\left(R^{2}\right)$ explained by each path. The study evaluated the following six goodness of fit indices: $x^{2}$-square test, the goodness-of-fit index (GFI), the adjusted goodness-of-fit index (AGFI), the comparative fit index (CFI), the Tuker-lewis Index(TLI), and root mean square error of approximation (RMSEA). For a good fit of the model, the TLI, GFI, CFI should be greater than or equal to 9.0 and $x^{2}$-square should be less than 3 [54]. Moreover, the adjusted goodness-of-fit index (AGFI) should be greater than 0.8 and the root mean square error of approximation (RMSEA) should be less than 0.08 [46]. Common criteria for (AMOS) have been suggested earlier and the outcomes are presented in Table VII and Table VIII. From these outcomes, the structural model indicates adequate fit with the observed data, in comparison with the suggested fit criteria.

TABLE VII: RESULTS OF THE STUDENT'S MODEL GOODNESS-OF-FIT

\begin{tabular}{|c|c|c|c|}
\hline Model fit index & Criteria & Values & References \\
\hline$x^{2} / \mathrm{df}$ & $<3.0$ & 1.784 & [54] \\
\hline Goodness-of-fit index (GFI) & $>=0.9$ & .90 & [55] \\
\hline Tuker-lewis Index(TLI) & $>=0.9$ & .92 & {$[54]$} \\
\hline Comparative fit index(CFI) & $>=0.9$ & .93 & [55] \\
\hline $\begin{array}{l}\text { Adjusted goodness-of-fit index } \\
\text { (AGFI) }\end{array}$ & $>0.8$ & .87 & [46] \\
\hline $\begin{array}{l}\text { Root mean square error of } \\
\text { approximation (RMSEA) }\end{array}$ & $<0.08$ & .050 & [46] \\
\hline
\end{tabular}

\begin{tabular}{llll}
\multicolumn{4}{c}{ TABLE VIII: RESUlTS OF THE TEACHER's } \\
\hline Model fit index & Criteria & Values & References \\
\hline$x^{2} / \mathrm{df}$ & $<3.0$ & 1.31 & {$[54]$} \\
\hline Goodness-of-fit index (GFI) & $>=0.9$ & .90 & {$[55]$} \\
\hline Tuker-lewis Index(TLI) & $>=0.9$ & .97 & {$[54]$} \\
\hline Comparative fit index(CFI) & $>=0.9$ & .97 & {$[55]$} \\
\hline $\begin{array}{l}\text { Adjusted goodness-of-fit index } \\
\text { (AGFI) }\end{array}$ & $>0.8$ & .85 & {$[46]$} \\
\hline $\begin{array}{l}\text { Root mean square error of } \\
\text { approximation (RMSEA) }\end{array}$ & $<0.08$ & .041 & {$[46]$} \\
\hline
\end{tabular}

\section{RESULTS OF HYPOTHESIS TESTING}

Fig. 2 and Fig. 3 show the results of the structural model 1 and model 2. The test produces the standardized path coefficients between model constructs, and also their statistical significance. Moreover, the test offers the squared 
multiple correlation $\left(\mathrm{R}^{2}\right)$, which indicate the variance of the dependent constructs which can be shown by independent constructs.

In model 1, Perceived Usefulness to e-learning was predicted by social media $(\beta=.297, p<0.001)$. This variable explained $44 \%$ of the of the Perceived Usefulness $\left(R^{2}=0.44\right)$ Therefore, hypotheses H1a supported. Perceived Ease of Use was predicted by social media $(\beta=.228, p<0.001)$. This variable explained $36 \%$ of the of the Perceived Usefulness $\left(R^{2}=0.36\right)$. As a result, hypotheses $\mathrm{H} 2$ a supported.

Attitude towards Behaviour was predicted by Perceived Ease of Use $(\beta=.365, p<0.001)$ and Perceived Usefulness $(\beta$ $=.463, p<0.001)$. Those variables together explained $48 \%$ of the Attitude towards Behaviour $\left(R^{2}=0.48\right)$. Therefore, hypotheses $\mathrm{H} 3 \mathrm{a}$, and $\mathrm{H} 4 \mathrm{a}$ were supported. Attitude Towards Behaviour significantly $(\beta=.523, p<0.001)$ affects behavioural intention to use while explaining $27 \%$ of the variance in behavioural intention to use. Consequently, hypothesis H5a was supported.

In model 2, Perceived Usefulness to e-learning was predicted by social media $(\beta=.426, p<0.001)$. This variable explained $57 \%$ of the of the Perceived Usefulness $\left(R^{2}=0.57\right)$. Therefore, hypotheses H1b supported. Perceived Ease of Use was predicted by social media $(\beta=.360, p<0.001)$. This variable explained $40 \%$ of the of the Perceived Usefulness $\left(\mathrm{R}^{2}\right.$ = 0.40). As a result, hypotheses H2b supported.

Attitude towards Behaviour was predicted by Perceived Ease of Use $(\beta=.284, p<0.001)$ and Perceived Usefulness $(\beta=.661, p<0.001)$. Those variables together explained 0.69 percent of the Attitude towards Behaviour $\left(R^{2}=0.69\right)$. Therefore, hypotheses $\mathrm{H} 3 \mathrm{~b}$, and $\mathrm{H} 4 \mathrm{~b}$ were supported. Attitude Towards Behaviour significantly $(\beta=.799, p<0.001)$ affects behavioural intention to use while explaining $64 \%$ of the variance in behavioural intention to use. Consequently, hypothesis H5b was supported.

All the proposed alternate hypotheses have strong statistical support, since the coefficients are all positive, the influence are all positive.

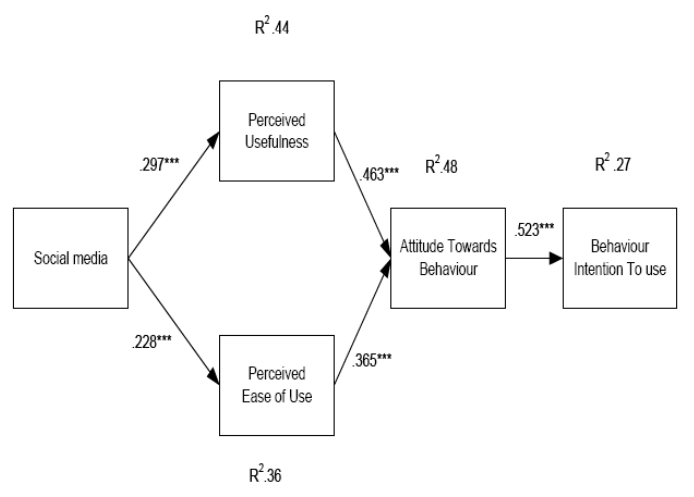

Fig. 2. Structural model results of students.

\section{DISCUSSION AND CONCLUSION}

The aim of this research is to examine the hypotheses related to the use of social networking media and examine how each is correlated with the perceived usefulness and perceived ease of use of e-learning in Libyan higher education. The main conclusion of this study is that Perceived Ease of
Use and Perceived Usefulness of social networking media are considered as the key factors in assessing the students' and teachers' behavioural intention of accepting and using e-learning in Libyan higher education. The result of this research shows that the use of social networking media plays an important role in the adoption of e-learning in Libyan higher education. As hypothesized, social networking media significantly affects both the Perceived Ease of Use and Perceived Usefulness for both students and teachers. Hence, when the social networking media is simple and easy to use, individual who feels that social media is more useful will have more intention to use e-learning technology for learning in Libya. Dwivedi, et al. [56] identified perceived ease of use and perceived usefulness as the key factors for adoption of e-learning. This study found that students and teachers who more readily used social networking media in their everyday lives tended to more positive perceptions of e-learning. Moreover, the study find stronger relationship between social media ease of use and accepting of e-learning. This research concurs with the research by Martin [57] stated that students and teachers who frequently and/or heavily use the social networking media have a high chance of accepting e-learning technology in their teaching and learning. In conclusion, the high rate of the use of social networking media have a positive impact on students and teachers in terms of the perceived ease of use of e-learning technology in Libyan higher education.

\section{REFERENCES}

[1] N. H. Jabr, "Social networking as a tool for extending academic learning and communication," International Journal of Business and Social Science, vol. 2, pp. 93-102, 2011.

[2] W. M. Al-rahmi, M. S. Othman, and M. A. Musa, "The improvement of students' academic performance by using social media through collaborative learning in Malaysian higher education," Asian Social Science, vol. 10, 2014.

[3] E. Hargittai, "Whose space? Differences among users and non - Users of social network sites," Journal of Computer - Mediated Communication, vol. 13, pp. 276-297, 2007.

[4] E. Dahlstrom, ECAR National Study of Undergraduate Students and Information Technology, 2011: EDUCAUSE Center for Applied Research, 2011.

[5] C. Greenhow, B. Robelia, and J. E. Hughes, "Learning, teaching, and scholarship in a digital age Web 2.0 and classroom research: What path should we take now?" Educational Researcher, vol. 38, pp. 246-259, 2009 .

[6] C. Redecker, K. Ala-Mutka, M. Bacigalupo, A. Ferrari, and Y. Punie, "Learning 2.0: The impact of Web 2.0 innovations on education and training in Europe," Final Report: European Commission-Joint Research Center-Institute for Porspective Technological Studies, Seville, 2009.

[7] A. L. Harris and A. Rea, "Web 2.0 and virtual world technologies: A growing impact on IS education," Journal of Information Systems Education, vol. 20, 2009.

[8] F. Fischer and H. Mandl, "Knowledge convergence in computer-supported collaborative learning: The role of external representation tools," The Journal of the Learning Sciences, vol. 14, pp. 405-441, 2005.

[9] T. Kenan, C. Pislaru, A. Othman, and A. Elzawi, "The social impact and cultural issues affecting the e-learning performance in Libyan Higher education institutes," International Journal of Information Technology \& Computer Science, vol. 12, 2013.

[10] A. Elkaseh, K. W. Wong, and C. C. Fung, "The impact of teaching and learning styles on behavioural intention to use e-learning in Libyan higher education," International Review of Contemporary Learning Research, pp. 25-34, 2014

[11] A. Rhema and I. Miliszewska, "Towards e-learning in higher education in Libya," Issues in Informing Science and Information Technology, vol. 7, pp. 423-7, 2010. 
[12] C. L. Coyle and H. Vaughn, "Social networking: Communication revolution or evolution?" Bell Labs Technical Journal, vol. 13, pp. 13-17, 2008.

[13] S. Downes, "Feature: E-learning 2.0," Elearn Magazine, vol. 2005, p. 1, 2005.

[14] L. Jonnavithula and A. Tretiakov, "A model for the effects of online social networks on learning," presented at Ascilite Conference, 2012.

[15] A. Kamenetz, "Gates foundation bets on facebook app to help kids graduate," Fast Company, vol. 14, 2011.

[16] R. Harrison and M. Thomas, "Identity in online communities: Social networking sites and language learning," International Journal of Emerging Technologies and Society, vol. 7, pp. 109-124, 2009.

[17] J. H. Al-ammary, A. K. Al-sherooqi, and H. K. Al-sherooqi, "The acceptance of social networking as a learning tools at University of Bahrain," International Journal of Information and Education Technology, vol. 4, no. 2, 20014.

[18] N. Jones, H. Blackey, K. Fitzgibbon, and E. Chew, "Get out of MySpace!" Computers \& Education, vol. 54, pp. 776-782, 2010.

[19] A. Schroeder, S. Minocha, and C. Schneider, "Social software in higher education: The diversity of applications and their contributions to students' learning experiences," Communications of the Association for Information Systems, vol. 26, pp. 547-564, 2010.

[20] A. Schroeder, S. Minocha, and C. Schneider, "Social software in higher education: The diversity of applications and their contributions to students' learning experiences," Communications of the Association for Information Systems, vol. 26, p. 25, 2010.

[21] S. G. Mazman and Y. K. Usluel, "Modeling educational usage of Facebook," Computers \& Education, vol. 55, pp. 444-453, 2010.

[22] W. Rifkin, N. Longnecker, J. Leach, L. Davis, and L. Orthia, "Motivate students by having them publish in new media: An invitation to science lecturers to share and test," presented at the Australian Conference on Science and Mathematics Education, 2012.

[23] I. Rowlands, D. Nicholas, B. Russell, N. Canty, and A. Watkinson, "Social media use in the research workflow," Learned Publishing, vol. 24, pp. 183-195, 2011.

[24] A. Dillon and M. G. Morris, "User acceptance of new information technology: theories and models," 1996.

[25] F. D. Davis, R. P. Bagozzi, and P. R. Warshaw, "User acceptance of computer technology: a comparison of two theoretical models," Management Science, vol. 35, pp. 982-1003, 1989.

[26] F. Wahid, "Using the technology adoption model to analyze Internet adoption and use among men and women in Indonesia," The Electronic Journal of Information Systems in Developing Countries, vol. 32, 2007.

[27] F. D. Davis, "User acceptance of information technology: System characteristics, user perceptions and behavioral impacts," 1993.

[28] X. Deng, W. J. Doll, A. R. Hendrickson, and J. A. Scazzero, "A multi-group analysis of structural invariance: an illustration using the technology acceptance model," Information \& Management, vol. 42, pp. 745-759, 2005.

[29] S.-H. Liu, H.-L. Liao, and J. A. Pratt, "Impact of media richness and flow on e-learning technology acceptance," Computers \& Education, vol. 52, pp. 599-607, 2009.

[30] C. Adamson. (2012). The Role of Social Media in Education. [Online]. Available:

http://www.icwe.net/oeb_special/OEB_Newsportal/the-role-of-socialand-mobile-media-in-education/

[31] C. Jackson. (2011). Teaching Tolerance: Your students love social media and so can you. [Online]. Available: http://www.tolerance.org/magazine/number-39-spring-2011/feature/y our-students-love-social-media-and-so-can-you

[32] N. Friesen and T. Anderson, "Interaction for lifelong learning," British Journal of Educational Technology, vol. 35, pp. 679-687, 2004.

[33] W. J. Doll and G. Torkzadeh, "Developing a multidimensional measure of system-use in an organizational context," Information \& Management, vol. 33, pp. 171-185, 1998.

[34] M. Srite, "Culture as an explanation of technology acceptance differences: an empirical investigation of Chinese and US users," Australasian Journal of Information Systems, vol. 14, 2006.

[35] T. Teo, "Factors influencing teachers' intention to use technology: Model development and test," Computers \& Education, vol. 57, pp. 2432-2440, 2011.

[36] M. H. Seif, M. R. Sarmadi, I. Ebrahimzadeh, and H. Zare, "A model for predicting intention to use e-learning based on epistemological beliefs," Life Science Journal, vol. 9, pp. 926-929, 2012.

[37] M. Fishbein and I. Ajzen, Belief, Attitude, Intention and Behavior: An Introduction to Theory and Research, 1975.
[38] J. E. Woodrow, "Locus of control and student teacher computer attitudes," Computers \& Education, vol. 14, pp. 421-432, 1990.

[39] A. Rhema, I. Miliszewska, and E. M. Sztendur, "Attitudes towards e-learning and satisfaction with technology among engineering students and instructors in Libya," presented at Informing Science \& IT Education Conference, 2013.

[40] Y. Zhao and F. L. Bryant, "Can teacher technology integration training alone lead to high levels of technology integration? A qualitative look at teachers' technology integration after state mandated technology training," Electronic Journal for the Integration of Technology in Education, vol. 5, pp. 53-62, 2006.

[41] R. Bataineh and A. Baniabdelrahman, "Jordanian EFL students' perceptions of their computer literacy," International Journal of Education and Development Using ICT, vol. 2, 2006.

[42] M. K. Lee, C. M. Cheung, and Z. Chen, "Acceptance of Internet-based learning medium: The role of extrinsic and intrinsic motivation," Information \& Management, vol. 42, pp. 1095-1104, 2005.

[43] J. Y. Bakos and M. E. Treacy, "Information technology and corporate strategy: a research perspective," MIS Quarterly, pp. 107-119, 1986.

[44] F. J. Fowler, Survey Research Methods, vol. 1, Sage, 2009.

[45] G. E. Gorman, P. R. Clayton, S. J. Shep, and A. Clayton, "Qualitative research for the information professional: a practical handbook," 2005.

[46] J. F. Hair, R. E. Anderson, R. L. Tatham, and W. C. Black, Multivariate Data Analysis with Readings, New Jersey: Englewood, 1995.

[47] C. Fornell and D. F. Larcker, "Evaluating structural equation models with unobservable variables and measurement error," Journal of Marketing Research, pp. 39-50, 1981.

[48] J. F. Hair, R. L. Tatham, R. E. Anderson, and W. Black, Multivariate Data Analysis, Upper Saddle River, NJ: Pearson Prentice Hall, vol. 6, 2006.

[49] R. P. Bagozzi, "The self-regulation of attitudes, intentions, and behavior," Social Psychology Quarterly, pp. 178-204, 1992.

[50] J. Hair, Multivariate Data Analysis, vol. 6, 2006.

[51] C. Fornell and D. F. Larcker, "Evaluating structural equation models with unobservable variables and measurement error," Journal of Marketing Research (JMR), vol. 18, 1981.

[52] G. Garson. (2009). Validity. [Online]. Available: http://faculty.chass.ncsu.edu/garson/PA765/validity.htm

[53] D. Gefen and D. Straub, "A practical guide to factorial validity using PLS-GRAPH: Tutorial and annotated example," Communications of the Association for Information Systems, vol. 16, 2005.

[54] J. F. Hair, R. E. Anderson, R. L. Tatham, and W. Black, Multivariate Data Analysis, Upper Saddle River, 1998.

[55] R. L. Tatham and W. C. Black, Multivariate Data Analysis, vol. 1, pp. 1-19, New Jersey: Prcentice Hall, 1998.

[56] Y. K. Dwivedi, M. D. Williams, B. Ramdani, S. Niranjan, and V. Weerakkody, "Understanding factors for successful adoption of web 2.0 applications," ECIS, 2011

[57] R. G. Martin, "Factors affecting the usefulness of social networking in e-learning at German University of Technology in Oman," International Journal of e-Education, e-Business, e-Management and e-Learning, vol. 2, 2012.

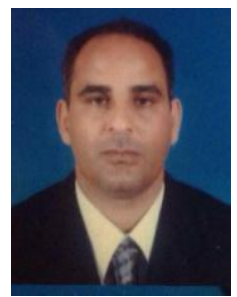

Ali Mohamed Elkaseh is currently a PhD student in School of Engineering and Information Technology at Murdoch University, South Street Campus, Murdoch, Western Australia. He held his master's degree in microprocessor systems from Belarusian State University of Information and Radioelectronics in 2005, Belarus. He held the bachelor's degree in computer science from University of Tripoli in Libya Prior to his $\mathrm{PhD}$ candidature, he was a full time lecturer, and a head of the Department of Computer Science at Elmergab University in Libya. His research interests include critical success factors of implementing e-learning in higher educational institutions, social networking media effect on behavior towards e-learning.

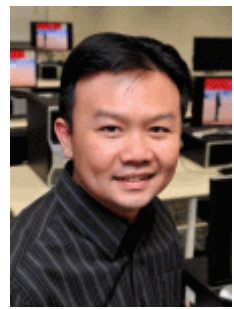

Kok Wai Wong is currently working as an associate professor with the School of Engineering and Information Technology at Murdoch University in Western Australia. He is the current the chapter chair for IEEE Systems, Man, and Cybernetics Society (WA Chapter). He is the vice president and Governing Board Member of the Asia Pacific Neural Network Assembly (APNNA). He is also serving as a member for the Emergent Technologies Technical Committee 
(ETTC) and Game Technical Committee (GTC) of the IEEE Computational Intelligence Society (CIS). Kevin Wong involved in the editorial boards for a number of international journals and in many international conference organising committees. He is the general conference co-chair for the 7th International Conference on e-Learning and Games, the 24th Australasian Joint Conference on Artificial Intelligence, the Second International Conference on Digital Interactive Media in Entertainment and Arts, and the Joint International Conference on Cyber Games and Interactive Entertainment. $\mathrm{He}$ is the program co-chair for the 21st International Conference on Neural Information Processing (ICONIP 2014).

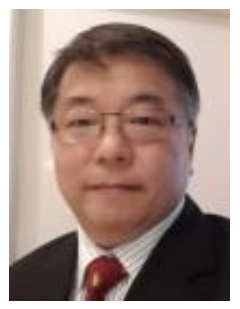

Chun Che Fung is an associate dean of research in the School of Engineering and Information Technology. He was trained as a marine radio and electronic officer from the Hong Kong Polytechnic and Brunel Technical College, Bristol UK. He graduated with a bachelor of science degree with first class honors in maritime studies and a master of engineering degree in system test technology, from the University of Wales, Cardiff, United Kingdom, and a
$\mathrm{PhD}$ degree from the University of Western Australia. He taught at the Department of Electronics and Communication Engineering, Singapore Polytechnic and at the School of Electrical and Computer Engineering, Curtin University of Technology. His research interest is in the development and applications of computational intelligent techniques for practical problems and technology for education. In addition, Lance is the current chair of the IEEE Australia Council and has also been nominated as a candidate for the IEEE Asia-Pacific Regional Director-Elect 2015-16. 